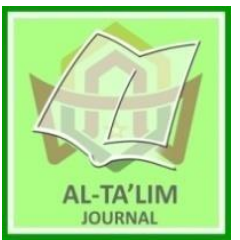

AL-TA'LIM JOURNAL, 28 (2), 2021, (155-166)

(Print ISSN 1410-7546 Online ISSN 2355-7893)

Available online at http://journal.tarbiyahiainib.ac.id/index.php/attalim

\title{
Madrasah Reposition in Building Community Trust in Covid-19 Era Disruption
}

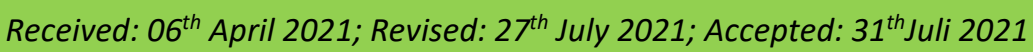

Permalink/DOI: http://dx.doi.org/10.15548/it.v28i2.694

\begin{abstract}
Ahmad Salim *)
Universitas Alma Ata, Yogyakarta, Indonesia.

E-mail: ahmadsalim0305@almaata.ac.id
\end{abstract}

\section{Muh. Mustakim}

Universitas Alma Ata, Yogyakarta, Indonesia.

E-mail: muh.mustakim@almaata.ac.id

\section{*) Corresponding Author}

\begin{abstract}
The advancement of information systems is an opportunity and a challenge as well as for Islamic educational institutions. One of them is a madrasah. If madrasah does not respond appropriately and wisely to this progress, madrasah will be left behind and even abandoned. Thus, in simple terms the era of "disruption" has been described by many recent scientists. In addition, the Covid-19 pandemic has implications for human life, including education. Online learning is a necessity. How has madrasah responded toward two major phenomena in the past of year. This study used a qualitative method with a case study approach. The primary data sources came from the research locus, namely MI Maarif Kokap and MTsN 4 Kulon Progo. Data collection techniques are carried out through interviews, documentation and interviews. Meanwhile, data analysis adopted a triangulation system. The results of the study describe that the two madrasahs carried out five strategic steps in building community trust, namely (1) following the dynamics of the community, (2) making learning innovations, (3) involving the surrounding community, (4) assigning offline learning under certain conditions and (5) home visit activity. These findings show that in building public trust during the pandemic and disruption era, madrasahs need to be open to existing technological developments, follow community dynamics and strengthen relationships with stakeholders.
\end{abstract}

Keywords: Covid-19; madrasa; social dynamics; social relations.

How to Cite: Salim, A., \& Mustakim, M. (2021). Madrasah Reposition in Building Community Trust in Covid19 Era Disruption. Al-Ta lim Journal, 28(2). doi:https://doi.org/10.15548/jt.v28i2.694.

\section{INTRODUCTION}

Juridically, madrasah is an educational institution under the authority of the Ministry of Religious Affairs of Republic of Indonesia in its management, both in relation to learning and other dimensions that are part of the system of an educational institution (Azra \& Afrianty, 2005; Hasyim \& Saat, 2020; Ropi, 2017). The level of madrasah is the same as school, only the nomenclature of names distinguishes between madrasah and school, namely the basic level which is commonly referred to as Madrasah Ibtidaiyah (MI) and Madrasah Tsanawiyah (MTs), and the middle level is Madrasah Aliyah (MA). Although institutionally the status of madrasah is under the authority of the Ministry of Religious Affairs of the Repulic of Indonesia, in reality there are more madrasah was managemed by the private/society than public madrasah (Jailani \& Harun, 2020). This reality provides the evidence to the public that the relationship between madrasah and society is a classic phenomenon that cannot be separated and has shaped the public knowledge. 
Madrasah as Islamic educational institutions, has several roles, including; realizing Islamic education which is based on the principles of thought, faith, and law, providing insight into values and morals and civilization in accordance with the context of the era (Abdul Mujib, 2006). The role has been played by this madrasah has logical consequences for the preservation of madrasah values which is mandatory by this institution, so that its existence can be felt by the community, and public trust in madrasah can be maintained (Istiyani, 2017; Mashud et al., 2021; Priatna, 2020; Sabki \& Hardaker, 2013).

Along with the development and dynamism of society that leads to rationality and capital setting, the public's perception of madrasah also has altered. Madrasah is not only required to keeper value and moral, but the performance of madrasah is expected to be able to meet the demands of society, namely the output of madrasah is required to has adequate knowledge on the aspects of science, technology and several non-academic skills that are in line with the demands of an increasingly dynamic workplace (Abdullah, 2017).

The increasingly rapid changes in society, especially during the corona pandemic, which forced all people in all parts of the world to be able to adjust to changes in all sectors of life, of course have a big correlation with madrasah (Fathurrochman, 2021; Mulyawan et al., 2020; Sartika et al., 2020; Sihombing \& Fatra, 2021). Madrasah has to be able to change and improve them in order to link to these enormous demands. Innovation and improvisation in all dimensions that exist in the madrasah component are a necessity in order to bring together the demands of society and must also pay attention to the values of Islamic education and local wisdom in the surrounding community (Abubakar, 2018; Erawati \& Rahmayanti, 2021; Kurnianto \& Lestarini, 2020).

During this difficult time, precisely there are several madrasahs located in mountainous areas that are able to maintain their building of trust in the community. Trust which is one of the madrasah social assets can be properly maintained by madrasah by making some improvisation efforts in learning activities. Some of these efforts to maintain trust have implications for an increase in the number of new students enrolling in madrasah in this era of disruption.

\section{METHOD}

This study describes social capital about the repositioning of madrasah in building public trust in the era of disruption and the Covid-19 pandemic. As part of qualitative research, the authors tend to choose to use case studies as a research approach (Yin, 2012). The consideration of selecting a research locus is that madrasah is able to survive and gain public trust despite the rapid changes in the "disruption" era and during the Covid-19 pandemic. This approach was also chosen because researcher needed to dig in depth.

The primary data source comes from the research field, while the secondary data comes from the literature related to research problems. Data collection was carried out through in-depth interviews, observation and documentation. Data analysis was carried out interactively (interactive analysis) through data reduction, data presentation, drawing conclusions and verification. The data analysis process is carried out by a cycle process and interactive interactions, so that they can complement each other (Miles \& Huberman, 2014).

\section{RESULT AND DISCUSSION}

\section{The Relationship between Covid 19 and the Existence of Madrasas}

Until now, no body can ascertain that the Covid 19 pandemic will end soon. In fact, the number of new cases in Indonesia still shows a significant increase in recent days. The Covid pandemic has broad implications for all sectors of life that are experiencing a setback, both in the economic, social, political sectors including the education sector, and madrasas are one of the crucial education 
sectors affected. Education, including madrasah, is a dimension that is highly dependent on dynamics in other sectors, so that changes that occur in the external dimension of madrasah will affect its sustainability either directly or indirectly (Hidayah et al., 2020).

The policy of psychological distancing and social distancing, as logical consequences of efforts to stop the spread of Covid 19, has destroyed the system and culture that had been built up in madrasah. The value system and madrasah culture is built and developed through several activities that prioritize togetherness, role model, mutual respect and respect between teacher and student in the context of transfer of knowledge, skills, and foster of values. Now, efforts to safeguard the values of madrasah which are full of togetherness and encounter are very difficult for madrasah to develop, even though this system and culture are the advantages and distinctions of madrasah compared to other educational institutions (Rochman et al., 2020).

Recognizing the delematous of this difficult time, the government issued a joint decree (SKB) between the four ministers regarding the implementation of learning at the beginning of 2020/2021, Mendikbud circular letter no 4 of 2020 concerning the implementation of educational policies during the Covid 19 emergency, as well as letter of the Director General of Islamic Education number 2791 of 2020 concerning emergency curriculum guides for madrasah that emphasize the development of character, noble morals, Islamic teaching and student independence. Through this emergency regulation, madrasah try to carry out all their activities that focus on learning to students by always paying attention to health protocols (Director General of Islamic Education, (Direktur Jendral Pendidikan Islam, 2020).

The above regulation requires madrasah to reposition and reorient all learning activities that are friendly to change, so that they can always be in line with the dynamics that occur in society, especially an activity that does not conflict with health protocols as a result of the Covid 19 pandemic. Accelerating online learning by not leaving the values and culture of Islam and Indonesian culture is one of the challenges that must be done by madrasah. Without being able to make these changes, madrasah will run into disorientation and dislocation and this condition will has implications for the existence of madrasah. The role and function of madrasah as educational institutions can be altered with other roles that can replace them with the power of mastery of technology.

The ability of madrasah to innovate and reorient to face the effects of the Covid 19 outbreak is also very varied, there are some madrasahs that can easily adjust by carrying out online-based learning activities, but on the other hand there are some who have difficulty making these changes. The success rate of madrasah in adapting to these social changes is greatly influenced by many factors. The internal condition of the madrasah, related to technology-literate human resources, the availability of facilities and infrastructure, the geographical location of the madrasah is one of the factors that makes it easier for madrasah to make demands for online-based learning. In addition, the social conditions of the community around the madrasah also affect the success of madrasah in effectively implementing online-based learning innovations. The level and socio-economic status of the parents of madrasah students, as well as the availability of physical facilities and infrastructure connected to the internet network are external factors that also greatly influence the success of all activities carried out by madrasah in the pandemic era. The ability of madrasah in conducting onlinebased learning is not automatically proportional to the success of madrasah in implementing learning without being followed by the abilities of the surrounding community, especially in the student parent setting (Salim, 2016).

Sociologically, the reality shows that most madrasahs are managemed by the private sector and are located in rural areas, especially in elementary level madrasah (MI and MTs). This condition correlates with the 
difficulties of madrasah in implementing online-based learning innovations. The condition of rural areas with lack infrastructure connected to the internet often becomes an obstacle for madrasah to conduct online learning effectively. Despite major advances in the information technology sector with non-cable internet innovations, the reality in rural areas is that difficulties in accessing the internet network are often encountered due to the unstable power grid constraints (Sunhaji, 2017).

In the context of Madrasah Ibtidaiyah Maarif Kokap and MTsN 4 Kulon Progo, the Covid 19 pandemic has changed and eliminated almost all programs or learning activities based on meetings or face-to-face meetings. Apart from classroom learning, some value strengthening activities that are carried out outside of the classroom are automatically not implemented by madrasahs. The absence of students going to the madrasah directly correlates to the absence of activities that involve students together, such as greetings, greetings, exercise together, sports and several extracurricular activities, which can hardly be implemented optimally.

Madrasah has to think and work hard to be able to carry out their functions as educational institutions that focus on the transfer of knowledge, values, skills amidst some of the limitations they have, both related to internal and external factors of the madrasah. The demands that exist in the 2020 emergency period regulations that emphasize the aspects of value, Isamic teaching and student independence are not easy to implement. Some of the efforts must be oriented towards meeting the needs of students both academically or in other skills and must also pay attention to the conditions of students who are affected by the spread of the virus. The closeness of student and teacher which is reflected in the handshake activity between teacher and student is an activity that cannot be done and must be replaced with virtual activities which psychologically will certainly reduce the essence of the noble values contained in these activities.

\section{Community Trust as Madrasah Social Capital}

Trust according to Putnam is a form of willingness to take risks in social relationships based on a feeling of confidence that other people will do something as expected and will always act in a mutually supportive pattern of action, at least other people will not act detrimental to themselves and their group. In line with Putnam, Fukuyama explained that trust is a very important side effect of cooperative social norms that will support social capital. Trust will be closely related to reciprocal relationships. If each party has the same expectations, both parties fulfill a high level of trust. Furthermore, Fukuyama explained that the real form of trust is honest, orderly behavior and can cooperate based on the agreed rules (Abrori \& Hadi, 2020; Munjin, 2017).

Based on the above notions of belief from Putnam and Fukuyama, then trust will occur if both parties do the same thing so that mutual trust occurs between the two and there is comfort on the axis that was created. A relationship of trust that only involves one party will certainly weaken this trust. Meanwhile, the trust that is built between two or more parties will have positive implications for social life. This reality is evidenced by the fact that the relationship of several people who have mutual trust in a social network will strengthen norms regarding the need to help each other.

Trust is a form of social capital that is very important to improve the relations and dialectics of madrasah with the community, which in turn is the development of madrasah in their evidentiary aspects. Without the trust of both levels, namely the madrasah and the community, some programs to improve the quality of madrasah will be difficult to materialize, moreover, some of these programs are directly related or directly related to the community. The existence of madrasah will be held hostage to their internal circle, and it is difficult to carry out some of the norms that exist in madrasah. 
The trust that is built between MI Maarif Kokap and MTsN 4 Kulon Progo and the community is not something instantaneous, but has been built for a long time, to be precise since the two madrasahs were founded until now and continues to increase. Of course, this belief building does not always develop linearly, but it fluctuates in accordance with the context of the relationship created between the two. Until now, public trust in these madrasas will continue to be consistent and become an effective madrasah social capital because community expectations of these two madrasas can be facilitated.

Some of these indicators are related to the increase in the number of new students, the involvement of madrasah activities by the community, namely prayer together before the National Examination and the outdor Islamic teaching. The fulfillment of community expectations for several programs implemented in madrasah is also a support for strengthening public trust in madrasah, which in turn is that people's preferences for madrasah are getting stronger and have increased.

Fulfillment of community expectations for madrasah has a positive and logical correlation to the solid building of public trust in the two madrasahs located in these mountainous areas. This reality can be seen in the acceptance of several learning programs during this emergency period. The community, especially parents of students, can accept and support activities organized by the madrasah. The two madrasahs, which are located in the center of Kokap and Girimulyo Subdistricts, are still the people's preference to continue their children's education with evidence of the increasing number of new students of these two madrasahs in the 2020/2021 academic year compared to the previous academic year, namely before the pandemic. The community can understand the limitations of the madrasah in providing online-based learning facilities, because this reality is also found in all existing educational institutions. Almost all educational institutions experience a shock culture regarding changes that occur in the community as a result of implementing health protocols.

All educational institutions are strongly demanded to be able to reposition their existence in a society that has undergone drastic changes due to the effects of the spread of Covid-19 (Hidayah et al., 2020). This drastic change necessitated the more ability madrasah to always interact and communicate with the community, because the strength of madrasah is in building relations with the community, without any support from the community, it is certain that the existence of madrasah will be decline and even extinction. The pressure for change that has an impact on the shock culture as described above has resulted in all educational institutions including madrasah still trying hard to find the right education format and in line with the developments that are taking place.

Efforts to prevent the spread of this dangerous virus cannot be carried out by government authorities alone, without the involvement of other sectors that have the authority to influence and guide the community (Widiyanto, 2020). Madrasah as educational institution has an important role to plays together with the government in making efforts to prevent the virus. Public trust in madrasah can be used as important capital for public literacy and education on the importance of building strong togetherness in the prevention and spread of this corona virus. The strength of madrasah lies in the function of madrasah as social institutions in society (Salim, 2020). As a social institution, the interactions and relationships that have been built so far can be used to "force", especially students, to comply with all existing rules, including rules related to health protocols. Madrasah as educational institution has the power to socialize the culture of new life to the community, because madrasah has the capital in the form of legality to construct values into objective reality through dialectics that occurs, namely externalization, which results in an objective reality. The ability of madrasah in carrying out socialization depends on the existence of symmetry between the objective world of 
society and the subjective world of individuals. (Dixon \& Berger, 2007). The students are part of the community subsystem, so the success of internalizing a value to students will of course also have implications for the daily life of students. in the families and communities, they live in. This condition will also have an impact on people's attitudes and behavior as a result of the interactions and relationships that occur.

Madrasah plays a major role in providing literacy to the community regarding the importance of preventing transmission of the Covid 19 virus in the community. Madrasah can provide literacy related to the threat of viruses that can endanger public health as well as the impact of prevention efforts which also greatly affect the multidimensionality of life. Without strong efforts to take precautions, the uncertainty of life in the community will last a long time. The impact of the corona effect on multi-sector life, especially in the economic, social and even political sectors, must be a reality and a lesson for society, because the education sector is a dimension that is very vulnerable to being influenced by other sectors. Madrasah has to be able to become role model for virus prevention efforts, through activities to comply with health protocols, providing several facilities and infrastructure that are loaded with efforts to comply with health protocols. Through the several roles played by these madrasas, it will be directly proportional to the maintenance of building public trust in madrasah. The community will assume that the difficulties faced by madrasah in implementing the learning process in this difficult era are a form of reasonableness faced by educational institutions in the transitional era in the context of the methods and approaches used by teachers.

Based on the concept of belief offered by Putnam and Fukuyama, the strength of the building of public trust in madrasah will be directly proportional to the fulfillment of community demands for madrasas. The fulfillment of some of the community's expectations for madrasah has proven to be able to strengthen public trust in madrasas. The existence of madrasas will be felt when some of these demands can be fulfilled by madrasah, especially during this difficult time. Facilitating the education process for students with an online model that can accommodate the interests of students' parents is one form of community demands and expectations for madrasas. Learning from home is a new culture and is called new normal education which has big implications for parents of students. Many parents have difficulty adjusting to this new culture, whether it is related to the low mastery of technology, economic conditions, or limited time to provide assistance for their children. So, communication that is intended through several channels that exist during this pandemic can always be used to maximize all activities carried out by madrasas, including learning with an online model. On the other hand, madrasah should always harmonize their demands on society. Community participation in several activities initiated and carried out by madrasah is a form of madrasah demands on the community.

\section{Madrasa efforts to build public trust in the Pandemic Era}

Madrasah is an educational institution which is a sub system of society. The education process in madrasah does not occur in an empty space, but is part of human activity which always intersects with other aspects that exist in a particular society. Education has been part of social change and if possible social change needs and can be influenced by education (Tilaar, 2002). The meaning of the linkages and relations between society and education is shown by how far education services to society, which in the end is a change for the better of society.

The education process is strongly influenced by the surrounding community, resulting in a dialogical relationship between the community as a system and the school as a sub-system in it. Even Miss. Namita P. Patil (Patil, 2012) states that; Education does not arise in response of the individual needs of individual, but it arise out the needs of the society of which the individual is members. The educational system of any society is related to its total social system. It 
is a sub system performing certain funtions for the on-going social system (Basha, 2017).

The relationship between society and education is a necessity that cannot be avoided, so the response of education to the dynamics of changing community values is a prerequisite so that these relationships can be maintained, so that the meaningfulness of the relations between sub-units in society can drive the dynamics of community change. Educational responses to the dynamics of cultural change and community values can be seen at the level of attitudes and educational participation in change that is displayed by the community. Response is the process of organizing and interpreting information that comes from outside the individual. The form of response can be seen from the action or actions of an individual after he has caught something from his five senses, this action can be in the form of rejecting or accepting what something is captured through his five senses (Garungan, 2008) (Heyes, 2008)

Madrasah in general is educational institution that is born from the community, so that the vision, mission and characteristics in the community will be in accordance with the characteristics of the madrasah, both in terms of culture, politics and economics ((Basuki, 2008) With this rationalization, the impact of the spread of Covid 19 which is felt by the community at large will become the attention of madrasah to maintain the trust of the people surrounding the madrasah. Without the madrasah making efforts to change the way of working in madrasah that is in accordance with the dynamics that exist in society, the public's trust in madrasah will decrease and may even be lost.

In order to strengthen and maintain trust in the community, MI Maarif Kokap and MTsN 4 Kulon Progo carry out several activities that always pay attention to the dynamics of community development. The two madrasahs have made several innovations in online learning, for example by developing teachers' abilities to master some of the features on smartphones for learning. The use of google form, google meet, youtube by teachers in conducting teaching activities is a form of learning media development that previously only focused on using the whatschap feature. Extra-curricular activities are also carried out virtually, in order to provide soft skill competencies to students, for example student council activities, scouting and religious activities. Despite the limitations of using online, some of these extra-curricular activities are able to convince parents that madrasahs can still show their existence as educational institutions that play an important role in developing the competence of students. Madrasah is seen as not only focusing on classroom learning that focuses on cognitive mastery, but can still present activities that provide reinforcement for students' skills, despite their limitations in this pandemic era. Religious activities for students are carried out by directly involving into Islamic teaching in each village according to the student's residence, and the supervising teacher is in control of the activities carried out with the community. This method automatically brings students closer to direct contact with community activities, students will get religious literacy from the community, and the community can put their trust in madrasah.

In order to complement some of the learning activities carried out online as described, madrasah also carry out offline learning activities. This activity is focused on several tasks that must be done by students, which are carried out by students or parents taking assignments that have been given by the teacher and then submitting the assignments according to the schedule determined by the teacher concerned. When students submit assignments, they also take other assignments given by other teachers with different subjects. The activity of students or parents of students taking and submitting assignments at this madrasah, carried out alternately according to the schedule agreed upon between the teacher and students, so that they still comply with the rules of health protocol.

There are several extra-curricular activities for student soft skill development that are still carried out in madrasah, because this activity is felt to be very difficult to do 
online mentoring, because the competence required of these activities is how to do, so this activity must be done face-to-face. The extracurricular activities carried out at MTsN 4 Kulon Progo were carried out through faceto-face mentoring, namely batik, badminton and bonsai activities. Meanwhile, at MI Maarif Kokap, activities that are still carried out at the madrasah are pencak silat and recitation. Some of these activities were not attended by many students, only student who registered and had an interested in related activities were allowed to carry out activities at the madrasah.

Another activity that is still carried out face-to-face by the madrasah is assistance for students who will take part in several competitions organized by the Ministry of Religion or subject teacher associations at the sub-district or district level. Mentoring is carried out by appointing a companion teacher according to their competence and scheduled periodically according to the competition schedule being held. Some students are required to register in several existing competitions, then, the assistant is tasked with selecting several existing students before they are fully mentored. In this way madrasas can build trust with madrasas by providing services to their students in accordance with the expectations demanded by the community, namely they are still able to provide various aspects needed by students, both on the academic and non-academic side.

In order to get closer to the parents of students, the madrasah also conducts visits to several student homes, especially for some students who have problems with learning. The supervising teacher is assigned to carry out activities outside this madrasah. Visit to the student's house is made in turns, according to the distance and route from the student's house. Teacher visit to students' homes is able to foster stability for students and parents of students, because they are able to conduct meetings between student and teacher. The saturation of students and parents with online learning can be cured by this activity. Parents of students felt very helpful and also felt that they were part of the activities carried out by the madrasah. The relationship between students and teachers that has been cut off due to the Covid pandemic can be reconnected.

The burden on parents as "substitute teachers" during the pandemic was reduced by the presence of teacher visiting several students' homes. The new culture that requires parents to act as teachers during the online learning period has created its own difficulties for parents of students, whether related to the material or content of learning, the use of learning tools, or related to the difficulty of dividing time with the work that must be done. The existence of teacher visits to students' homes is very helpful for students in increasing student motivation. This activity really made an impression mainly on madrasah grade 1 students for the Madrasah Ibtidaiyah level and 7 for the Madrasah Tsanawiyah level, because this class is students who have never carried out face-toface learning. They do not know their teacher fully yet, meetings between them are only facilitated through online media with various types used.

Madrasah also participate in several humanitarian activities in the community, for example condolence activity, mutual cooperation and community meetings held by residents at the hamlet, village or even subdistrict level. Representatives of teacher or madrasah education personnel carry out these activities while maintaining the implemented health protocols. This social and humanitarian activity is able to maintain and improve the relationship between the madrasah and the community. Madrasah is able to attend and be part of several activities in the community. The presence of madrasah in these community activities has implications for their attachment to the community and ultimately the relationship of trust can be maintained.

The reality in mountainous societies that places madrasah teachers as important figures in the social status of the community makes it easier and facilitates some community activities by involving the presence of teachers. Teacher plays a large role in many social and humanitarian activities in society, either as members of 
groups in society or as central figures in policy activities at the resident or hamlet level. The involvement of teacher in several community activities, apart from being caused by high assumptions on the social status of teacher, is also proven by their competence to be able to carry out key roles in activities carried out in the community quite well. The involvement and presence of madrasah teachers in many activities that exist in this community, is able to produce and maintain public trust in madrasah.

In order to convince the community that madrasah is still consistent as educational institution that is oriented towards learning for students, madrasah always communicate and socialize some of their implementation of activities to the community. Madrasah uses of existing information instruments such as gruop Whatschap (WA), Instagram and short message service (SMS) to convey some of the activities carried out. In this way, people can always quickly see some of the activities they are carrying out and they can respond to the activities that have been carried out. This method is a new form of socialization culture carried out by madrassas to the community as a result of pressure from the Covid 19 pandemic. The consequences of the prohibition to carry out communal activities involving many people force madrasah to improvise their forms of service to the public. Social media is the instrument most widely used to strengthen the relationship between madrasah and community interactions.

Through this online media, madrasah also provides outreach to the community in order to get new students in the 2020 academic year. Madrasah just needs to provide socialization to grade 6 students through zoom meetings about several rules related to new student registration. Parent of students can register their children online via mobile phones and do not need to come to the madrasah. This new method is seen to be able to deliver the desire of madrasah and people who will continue their education to madrasas. They can get full information on some of the advantages of madrasah, for example related to accreditation, academic and non-academic achievements, or some excellent madrasah activities, without having to go to the madrasah. Through this new method, new students in the 2020 academic year have actually increased from the previous year. This reality shows that public trust in madrasah can be maintained properly.

The power relation is still visible to seen in the context of the community around MI Maarif Kokap. This phenomenon can be seen in the strong influence of several religious figures in indoctrinating society to continue their children to madrasah and the community following and implementing this appeal. It has the power to produce knowledge and keep that knowledge into an institutional episteme. This method has proven to be effective in convincing public trust in madrasah, so that the number of new madrasah students always increases in following year and even outperforms several other schools, both public and private. Internal madrasah does not need to conduct outreach regarding new student admissions to prospective students at lower levels, but several madrasah networks have been conducted socialization.

According to Foucault's perspective, it can be seen that the role of power relations is played more as a guardian of the strength of the existing power, not necessarily associated with someone who has a structural position in power over his subordinates, but rather a person's ability to maintain the power relations they have, so that these relations staying awake with indicators can influence other individuals without coercive and intimidating pressure (Foucault, 2003). In the context of this mountainous society, the power relations are mostly played by priest, leaders of Islamic boarding schools who are members of the mainstream organizations, namely Nahdlatul Ulama and Muhammadiyah. Through the existing power relations knots supported by the satisfaction of the surrounding community for the existence of this madrasah, social capital in the form of trust will continue to increase and be maintained.

The public assumption that the spread of Covid 19 is mostly centralized in urban 
areas, which requires large crowds, also has a major influence on building public trust in madrasah. They feel safe from the threat of the dangers of Covid, if they continue to carry out their daily activities away from the crowds and bustle of the city, then the two madrasahs are located in mountain are still the options for continuing their children's education. In addition, the achievements of these two madrasahs also show their excellence, so that people's expectations of madrasah can be brought together at this level.

At this level, madrasah is able to strengthen their building of trust with the community with various efforts that has been made. Some forms of activities carried out by madrasah are supported and vice versa is clear evidence that between madrasah and the community there is a strong building of belief. The awareness of the madrasah in carrying out activities based on honesty and the desire for the progress of an existing system in society is the basis of trust that can always be developed and maintained.

Various learning activities carried out online can be communicated to the public, so that it can become public knowledge of the existence of madrasah as educational institutions that can still carry out their roles well. This knowledge will always be produced by madrasah in new ways that are different from previous activities as a consequence of changes in society due to the Covid pandemic. Public knowledge of the madrasah about its various advantages is subjective and relative, and is highly dependent on the relationships and interactions between the two that are built in a certain period. So trust also has a relative and subjective character and really depends on how much expectation they get from other parties. The greater the expectations they get from the other party, the stronger the trust of one party to another. The amount of expectation on a matter, including in the affairs of education, will be greatly influenced by public knowledge about what is expected from the education sector (Simamora, 2020).

\section{CONCLUSION RECOMMENDATION}

AND

The results of the research above describe, to strengthen and maintain trust in the community, MI Maarif Kokap and MTsN 4 Kulon Progo carry out several activities, namely: (1) always paying attention to the dynamics of community development. (2) madrasah carry out online learning innovations by developing the ability of teachers to operate several features on smartphones for learning, using google form, google meet, youtube. (3) Involving the surrounding community, namely directing student activities from home by involving the religius teaching in each village according to the student's residence, and the supervising teacher being the control over the activities carried out with the community. (4) Offline learning activities by means of student or parents taking assignments that have been given by the teacher and then submitting the assignments according to the schedule determined by the teacher concerned. Madrasah is also heavily involved in the community, such as humanitarian activities through visiting bereaved families, repositioning teachers as important figures in society and involving teachers in community activities. (5) home visiting, teacher visits several students' homes, especially to some student whose problems with learning. The supervisor teacher is assigned to carry out activities outside this madrasah. Visit to the student's house is made in turns, according to the distance and route from the student's house. The home visit activity received a good response from parents as "substitute teachers" during the pandemic period.

The result of the above research indicates that the repositioning of madrasah in building public trust in the era of disruption and the Covid-19 pandemic can be done by optimizing learning by utilizing technology and building relationships with students, parents and society. The social relation between madrasah and the community has to be maintained for the sake of the existence of these Islamic educational institutions. 


\section{REFERENCES}

Abdul Mujib, J. M. (2006). Ilmu Pendidikan Islam. Kencana Prenadamedia Gruop.

Abdullah, M. A. (2017). Islam as a cultural capital in Indonesia and the Malay world: A convergence of Islamic studies, social sciences and humanities. Journal of Indonesian Islam, 11(2), 307-328.

Abrori, M. S., \& Hadi, M. S. (2020). Integral Values in Madrasah: To Foster Community Trust in Education. Istawa: Jurnal Pendidikan Islam, 5(2), 160-178.

Abubakar, I. (2018). Strengthening core values pesantren as a local wisdom of islamic higher education through ma'had jami'ah. IOP Conference SEries: Earth and Environmental Science, 175(1), 012144.

Azra, A., \& Afrianty, D. (2005). Pesantren and Madrasa: Modernization of Indonesian Muslim Society. Workshop on Madrasa, Modernity and Islamic Education, Boston University, CURA.

Basha, C. (2017). Role of education in social change. International Journal of Advanced Educational Research, 2(5), 236-240.

Basuki. (2008). Madrasah: Learning Society Dan Civil Society (Potret Madrasah Aliyah Negeri 3 Malang). Edukasi: Jurnal Penelitian Pendidikan Agama Dan Keagamaan, 6(2), 39-61.

Direktur Jendral Pendidikan Islam. (2020). Keputusan Direktur Jenderal Pendidikan Islam No 2581 Tahun 2020. Journal of Chemical Information and Modeling.

Erawati, D., \& Rahmayanti, R. (2021). Development of Local Wisdom-based Islamic Education Learning Material for Secondary School Students: A Design-based Research. Jurnal Iqra': Kajian Ilmu Pendidikan, 6(2), 148165.
Fathurrochman, I. (2021). Online Evaluation System in the Pandemic Disruption in Madrasah: Opportunities and Challenges Based on Qualitative Report. Jurnal Iqra': Kajian Ilmu Pendidikan, 6(2), 184-197.

Garungan, W. A. (2008). Psikologi Sosial. Eresco.

Hasyim, S., \& Saat, N. (2020). The Genesis Of The Ministry Of Religious Affairs. In Indonesia's Ministry of Religious Affairs under Joko Widodo (pp. 3-9). ISEAS Publishing.

Heyes, M. H. dan S. (2008). Pengantar Psikologi, Alih Bahasa, Soenardji. Erlangga.

Hidayah, K., Salim, A., \& Mustakim, M. (2020). Scientific Approach to the Learning of Islamic Religious Education in the Covid-19 Period: A Study in Bunut Hulu State High School. IWOS: Islam in World Perspectives Symposium, 1(1), 167176.

Istiyani, D. (2017). Tantangan dan Eksistensi Madrasah Diniyah sebagai Entitas Kelembagaan Pendidikan Keagamaan Islam di Indonesia. Edukasia Islamika, 127-145.

Jailani, M. S., \& Harun, M. H. (2020). Education Empowerment of Madrasah at Fisherman Society in Suku Laut Kuala Tungkal Jambi. Al-Ta Lim Journal.

Kurnianto, R., \& Lestarini, N. (2020). Integration Of Local Wisdom In Education. International Seminar on Education, 557-563.

Mashud, I., Suradika, A., \& Ahmad, G. (2021). Quality Management of Islamic Educational Institutions Service (Study of Customer Satisfaction Analysis in Madrasah Ibtidaiyah Al-Husna Ciledug Tangerang City). International 
Journal of Educational Management and Innovation, 2(1), 55-67.

Miles, M. B., \& Huberman, A. M. (2014). Analisis Data Kualitatif: Buku Sumber tentang metode-metode Baru terj. Tjetjep Rohendi Rohidi; Qualitative Data Analysis. UI-Press.

Mulyawan, M., Listy, C. Z., Al-Ghoniyu, M., \& Sutarman, S. (2020). The challenges of ISMUBA online learning in madrasah of pandemic era. Islam in World Perspectives Symposium, 1(1), 183-188.

Munjin, M. (2017). Social Capital: Trust Building As A Strategy Of Developing Madrasa (A Case Study at Islamic Elementary School (MI) Istiqomah Sambas Purbalingga). AlHayat: Journal of Islamic Education, 1(1), 40-71.

Patil, N. P. (2012). Role Of Education In Social Change. International Educational E-Journal.

Priatna, T. (2020). Demography of Madrasah Diniyah Takmiliyah and revitalizing Sartika, F., Ritonga, M., \& Rasyid, A. (2020). Implementation of Islamic Religious Education in Madrasah Ibtidaiyah During Covid-19 Pandemic. Khalifa: Journal of Islamic Education, 4(2), 1442.

Sihombing, A. A., \& Fatra, M. (2021). Distance Learning During the Pandemic Era: Online Learning Experiences of State Madrasah Tsanawiyah Students During Covid19 in Indonesia. Anal. J. Soc. Sci. Relig, 6, 95-112.

Simamora, R. M. (2020). The Challenges of Online Learning during the COVID- the institutional function of Islamic education. Journal of Southwest Jiaotong University, 55(1).

Rochman, C., Nasrudin, D., Rokayah, R., Mulyani, S., Pertiwi, C. S. R., \& Ginanjar, G. (2020). Distance Learning During The Covid-19 Pandemic: Strengthening Of Character, Productivity, And Stem Competency. Jurnal Pena Sains.

Ropi, I. (2017). The Ministry of Religious Affairs, the Muslim Community and the Administration of Religious Life. In Religion and Regulation in Indonesia (pp. 101-116). Springer.

Sabki, A. A., \& Hardaker, G. (2013). The madrasah concept of Islamic pedagogy. Educational Review, 65(3), 342-356.

Salim, A. (2016). Pendekatan Saintifik Dalam Pembelajaran Pendidikan Agama Islam (PAI) Di Madrasah. Cendekia: Jurnal Kependidikan Dan Kemasyarakatan.

19 Pandemic: An Essay Analysis of Performing Arts Education Students. Studies in Learning and Teaching.

Sunhaji. (2017). Between social humanism and social mobilization: The dual role of Madrasah in the landscape of Indonesian Islamic education. Journal of Indonesian Islam, 11(1), 125-144.

Tilaar, H. A. R. (2002). Perubahan Sosial dan Pendidikan, Pengantar Pedagogik Transformatif Untuk Indonesia. PT. Grasindo.

Yin, R. K. (2012). Case study methods. In Handbook of Complementary Methods in Education Research. 